\title{
The Effect of Growth Medium Composition on X.campestris Metabolism in Producing Xanthan Gum
}

\author{
Nancy Siti Djenar ${ }^{*}$ and Edi Wahyu Sri Mulyono ${ }^{1}$ \\ ${ }^{1}$ Chemical Engineering Department, Politeknik Negeri Bandung, Bandung 40012, Indonesia
}

\begin{abstract}
In the fermentation industry, the role of medium is very important in increasing the growth rate of microbes. Nutrient Agar (NA) is one of the common medium used for growth and increase regeneration X.campestris, while Luria-Bertani medium (LB) is usually used for matters related to X.campestris productivity in producing xanthan gum. To increase the productivity of $X$.campestris and xanthan gum rendement, this research used medium variation of Nutrient Broth (NB) added with mineral plus inducer and Luria-Bertani Broth (LBB) with 4\% substrate of liquid sugar and $2 \%$ maize, respectively. Based on FT-IR analysis, both substrates can produce xanthan gum which qualitatively has been compatible with commercial xanthan gum. The $4 \%$ liquid sugar yielded of $34.20 \%-57.88 \%$, while $2 \%$ maize was $54.93 \%-73.61 \%$. The use of NB and LBB produced xanthan gum with viscosity of $28-31 \mathrm{cPs}$ and $15-30 \mathrm{cPs}$, respectively. These viscosity values indicated that xanthan gum can be used as a thickener in its application in industry. Precipitation using a combination of salt with IPA did not provide significant changes to the xanthan gum gain. This is due to the low number of bonds between the cations of the salt and the anions of the xanthan solution.
\end{abstract}

\section{Introduction}

Xanthan gum is one of the natural carbohydrate polymers which are now used as thickening ingredients ranging from the food industry to mining. Xanthan gum belongs to the group of hydrophilic colloidal sap (hydrocolloid) produced by the fermentation process of the Xanthomonas campestris bacteria.

In Indonesia, the use of xanthan gum in the food and beverage industry began around the 1980s. Since its inception in the industry until now, xanthan gum is still imported because there is no domestic industry capable of producing the biopolymer [1].

Substrates for the production of gum xanthan are carbohydrate compounds such as sorbitol, starch, potato starch, or hydrolyzate from molasses for carbon sources, while the nitrogen source may use hydrolyzate from casein, soybean waste, or cell hydrolyzate [2]. X.campestris fermentation using liquid sugar substrate at certain process conditions can produce xanthan gum between $7.9147-13.8421 \mathrm{~g} / \mathrm{L}$, yield $36.52 \%$ with highest viscosity $11.1453 \mathrm{cPs}$ [3].

The process of gum xanthan formation is very complicated and not widely known. The mechanism of its formation simply by enzymatic transglycoside reaction. The enzyme responsible for this reaction is cyclodextrin glucanotransferase (1,4- $\alpha$-D-1,4-glucotransferase, EC 2.4.1.19) abbreviated to CGTase. CGTase is one of the important industrial enzymes that play a role in the cyclization process, which converts starch and $\alpha-1,4$ glycosidic to cyclodextrin via intramolecular transglycosylation reaction. In addition, this enzyme can also hydrolyze starch and cyclodextrin becomes simpler [4]. According to D.S Prastiko [5] X. campestris produces a high activity CGTase enzyme. Therefore, in this research X.campestris cultures were grown in NA medium with an inducer, also grown on Luria-Bertani (LB) medium containing tripton. So it is expected in the process of metabolism X.campestris can increase its productivity in producing CGT ase enzyme. Furthermore, this enzyme will perform transglycoside reaction to produce xanthan gum. The objective of this research studied the effect of growth medium composition on X.campestris to increase xanthan gum production.

\section{Experimental Details}

\subsection{Microbial Preparation}

At this stage regeneration of bacteria $\mathrm{X}$. campestris on:

a) Nutrient Agar (NA) medium containing nutrient agar + mineral + inducer and incubated at $28^{\circ} \mathrm{C}$.

b) Luria-Bertani (LB) agar medium containing yeast extract, tryptone, $\mathrm{NaCl}$ plus agar and incubated at $28^{\circ} \mathrm{C}$.

Corresponding author: nancysitidjenar@yahoo.com 


\subsection{The production of inculum of X. campestris}

\subsubsection{The production of inoculum of $X$. campestris in modified Nutrient Broth (NB).}

Modified Nutrient Broth medium was prepared by dissolving $0.3 \mathrm{~g}$ beef extract, $0.5 \mathrm{~g} \mathrm{NaCl}, 0.5 \mathrm{~g}$ of glucose, mineral and $0.1 \mathrm{~g}$ inducer in an erlenmeyer that contained $100 \mathrm{ml}$ of distilled water. The medium was sterilized for 20 minutes at $121^{\circ} \mathrm{C}$ and $1.4 \mathrm{~atm}$. The stock culture X. campestris in nutrient agar was inoculated to the modified NB medium and incubated at $28^{\circ} \mathrm{C}$ for 48 hours and stirred at $150 \mathrm{rpm}$.

\subsubsection{The production of inoculum of $X$. campestris in Luria-Bertani Broth (LBB).}

This Broth medium was prepared by dissolving yeast extract, tryptone, $\mathrm{NaCl}$ in an erlenmeyer that contained $100 \mathrm{ml}$ of distilled water. The medium was sterilized for 20 minutes at $121^{\circ} \mathrm{C}$ and $1.4 \mathrm{~atm}$. The stock culture X. campestris in LB agar was inoculated to the LBB medium and incubated at $28^{\circ} \mathrm{C}$ for 48 hours and stirred at $150 \mathrm{rpm}$.

\subsection{Experimental Work}

Aerobic fermentation was done at $250 \mathrm{rpm}, 28^{\circ} \mathrm{C}$ for 72 hours using $4 \%$ liquid sugar and $2 \%$ maize as substrates with additive substances (Table 1).

Table 1. Variation of medium and substrate on xanthan gum production.

\begin{tabular}{|c|c|c|c|c|}
\hline \multirow{2}{*}{ No } & \multicolumn{2}{|c|}{ Growth Medium } & \multirow{2}{*}{$\begin{array}{l}\text { Types of } \\
\text { substrate }\end{array}$} & \multirow{2}{*}{ Types of mineral } \\
\hline & $\begin{array}{l}\text { Slant } \\
\text { Agar }\end{array}$ & Inoculum & & \\
\hline 1 & $\begin{array}{l}\text { NA + } \\
\text { induc } \\
\text { er }\end{array}$ & $\begin{array}{l}\mathrm{NB}+ \\
\text { inducer }\end{array}$ & $\begin{array}{l}4 \% \\
\text { liquid } \\
\text { sugar }\end{array}$ & $\begin{array}{l}\mathrm{FeCl}_{3} \cdot 6 \mathrm{H}_{2} \mathrm{O} \\
\mathrm{MgCl}_{2}, \mathrm{ZnCl}_{2}, \\
\mathrm{KH}_{2} \mathrm{PO}_{4}, \mathrm{Na}_{2} \mathrm{SO}_{4}, \\
\mathrm{H}_{3} \mathrm{BO}_{3}, \mathrm{CaCO}_{3}\end{array}$ \\
\hline 2 & LB & LBB & $\begin{array}{l}2 \% \\
\text { maize }\end{array}$ & $\begin{array}{l}(\mathrm{NH})_{2} \mathrm{SO}_{4}, \mathrm{MgSO}_{4}, \\
\mathrm{CaSO}_{4}, \mathrm{MnSO}_{4}, \\
\mathrm{FeSO}_{4} \text {, buffer Na- } \\
\text { phosphate }\end{array}$ \\
\hline
\end{tabular}

Pasteurization. The pasteurization was done at $90^{\circ} \mathrm{C}$ for 25 minutes. The pasteurized fermentation was separated between its xanthan solution and its cells using centrifugation.

Purification and precipitation. Precipitation of xanthan gum was done by added an organic solvent of isopropyl alcohol (IPA) with a ratio of 1: 1, 2: 1, 3: 1 (v/ v) to the supernatant, and with and without salt addition. The obtained precipitate was then dried in an oven at $50^{\circ} \mathrm{C}$, weighed, and the yield and rendement were calculated. Analysis of xanthan gum was consisted of viscosity, FTIR and HPLC analysis.

\section{Result and Discussion}

The first step of this research was the preparation of $4 \%$ liquid sugar and $2 \%$ maize. Purification of X.campestris by regenerating it into two types of growth medium were Nutrien Agar (NA) and Luria-Bertani (LB) using dilution method. To the substrate was added some minerals to support the growth of X. campestris during fermentation. The inoculum medium used were Nutrient Broth (NB) and Luria-Bertani Broth (LBB). Fermentation was carried out at $28^{\circ} \mathrm{C}, 250 \mathrm{rpm}$ for 72 hours aerobically within the incubator shaker.

Based on the results of FTIR analysis, the presence of functional groups in the xanthan gum obtained from various fermentation process conditions can be recognized. Figure 1 and 2 show the FTIR spectrum of xanthan gum using modified NB and LBB with $4 \%$ liquid sugar and $2 \%$ maize, respectively.

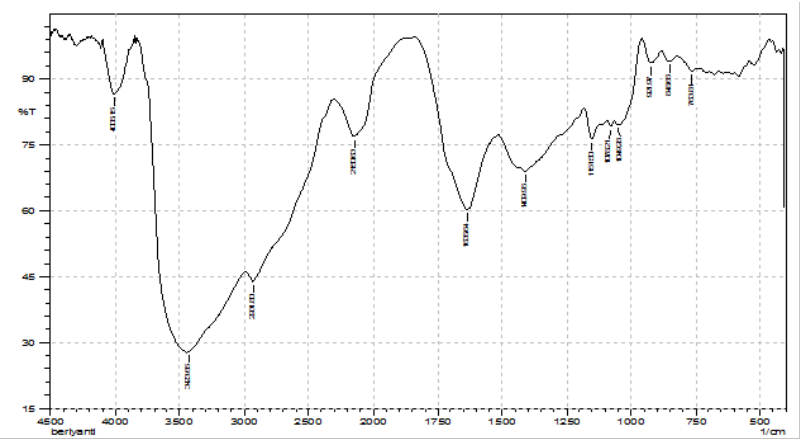

Fig. 1. FTIR Spectrum of Xanthan Gum from X. campestris Fermentation Using a Modified Nutrient Broth Medium with a Substrate of $4 \%$ Liquid Sugar.

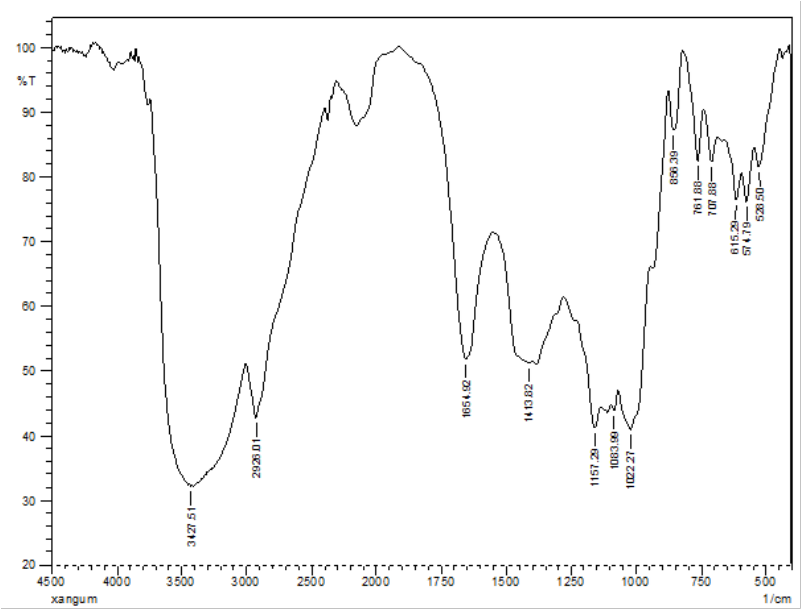

Fig. 2. FTIR Spectrum of Xanthan Gum from X. campestris Fermentation Using a Luria-Bertani Broth Medium with a Substrate of $2 \%$ Maize.

Based on FTIR analysis results, it can be seen the existence of functional groups contained in xanthan gum from fermentation $4 \%$ liquid sugar and $2 \%$ maize. The comparison of functional groups between commercial xanthan gum and xanthan gum of the study using two medium types is shown in Table 2 below.

Table 2 showed the compatibility of functional groups between xanthan gum of the study and commer- 
Table 2. The Comparison of functional groups in commercial xanthan gum and in xanthan gum obtained using two types of medium.

\begin{tabular}{|c|c|c|c|c|c|c|c|c|}
\hline Annotation & $\begin{array}{c}-\mathrm{OH} \\
(3600- \\
3000 \\
\left.\mathrm{~cm}^{-1}\right) \\
\end{array}$ & $\begin{array}{c}-\mathrm{CH}_{2} \\
(3000- \\
2800 \\
\left.\mathrm{~cm}^{-1}\right) \\
\end{array}$ & $\begin{array}{c}-\mathrm{C}=\mathrm{O} \\
(1760- \\
1690 \\
\left.\mathrm{~cm}^{-1}\right) \\
\end{array}$ & $\begin{array}{c}-\mathrm{C}=\mathrm{O} \\
\text { from } \\
\text { pyruvate } \\
\mathrm{cm}^{-1}\end{array}$ & $\begin{array}{l}-\mathrm{COO}- \\
\mathrm{cm}^{-1}\end{array}$ & $\begin{array}{c}-\mathrm{C}-\mathrm{O}-\mathrm{C}- \\
\mathrm{cm}^{-1}\end{array}$ & $\begin{array}{c}\text {-C-O-C-O- } \\
\text { C acetal } \\
\mathrm{cm}^{-1}\end{array}$ & $\begin{array}{c}\mathrm{C}_{2} \mathrm{H} \text { from } \\
\beta \text {-glycoside } \\
\mathrm{cm}^{-1}\end{array}$ \\
\hline $\begin{array}{l}\text { Xanthan Gum } \\
\text { Commercial }\end{array}$ & 3427,85 & 2922,59 & 1733,69 & 1623,77 & 1410,67 & 1277,61 & $\begin{array}{l}1159,01- \\
1028,84\end{array}$ & 795,49 \\
\hline $\begin{array}{l}\text { Xanthan Gum } \\
\text { (NB, using 4\% } \\
\text { liquid sugar) }\end{array}$ & 3423.65 & 2931.80 & & 1635.64 & 1409.96 & & $\begin{array}{c}1049.28- \\
1078.21\end{array}$ & 848.68 \\
\hline $\begin{array}{l}\text { Xanthan Gum } \\
\text { using (LBB, 2\% } \\
\text { maize) }\end{array}$ & 3427,51 & 2926,01 & & 1654,92 & 1413,82 & & $\begin{array}{l}1022,27- \\
1157,29\end{array}$ & 856,39 \\
\hline
\end{tabular}

Table 3. Xanthan gum research result.

\begin{tabular}{|c|c|c|c|c|c|c|c|c|c|}
\hline \multicolumn{5}{|c|}{ Nutrien Broth (NB) + Mineral + Inducer 0,083\% } & \multicolumn{5}{|c|}{ Luria-Bertani Broth (LBB) } \\
\hline $\begin{array}{l}\text { Yield } \\
(\mathrm{g} / \mathrm{L})\end{array}$ & $\begin{array}{l}\text { Dry Cells } \\
(\mathrm{g} / \mathrm{L})\end{array}$ & $\begin{array}{l}\text { Rendement } \\
(\%)\end{array}$ & $\begin{array}{l}\text { Viscosity } \\
\text { (cPs) }\end{array}$ & Solvent & $\begin{array}{l}\text { Yield } \\
(\mathrm{g} / \mathrm{L})\end{array}$ & $\begin{array}{l}\text { Dry cells } \\
(\mathrm{g} / \mathrm{L})\end{array}$ & $\begin{array}{l}\text { Rendement } \\
(\%)\end{array}$ & $\begin{array}{l}\text { Viscosity } \\
\text { (cPs) }\end{array}$ & Solvent \\
\hline 23,35 & 1,48 & 57,88 & 31 & IPA $(1: 2)$ & 22,20 & 3,16 & 73,61 & 15 & $\begin{array}{l}\text { IPA } \\
(1: 3)\end{array}$ \\
\hline 23,15 & 1,48 & 57,88 & 31 & $\begin{array}{c}\text { IPA }(1: 2) \\
+\mathrm{NaCl} \\
0,1 \%\end{array}$ & 22,08 & 3,16 & 73,61 & 15 & $\begin{array}{c}\text { IPA }(1: 3) \\
+\mathrm{NaCl} \\
0,1 \%\end{array}$ \\
\hline 13,68 & 3,36 & 34,20 & \pm 28 & IPA $(1: 2)$ & 16,48 & 8,72 & 54,93 & 30 & IPA (1:3). \\
\hline 22,91 & 1,67 & 57,28 & \pm 30 & $\begin{array}{c}\text { IPA (1:2) } \\
+\mathrm{NaCl} \\
0,1 \%\end{array}$ & 18,57 & 7,68 & 61,90 & 25 & $\begin{array}{c}\text { IPA }(1: 3) \\
+\mathrm{NaCl} \\
0,1 \%\end{array}$ \\
\hline
\end{tabular}

cial gum xanthan, in particular the presence of pyruvate and acetal groups. This suggests that the fermentation of X.campestris using the liquid sugar substrate and maize under certain conditions of process can qualitatively produce xanthan gum.

Overall, the results of this study can be shown in Table 3 as shown above.

In Table 3 it was shown that in $\mathrm{X}$. campestris fermentation both of type and medium composition greatly affect cell growth and the amount of product obtained. Based on the acquisition of the product (yield, g / L) from both medium have almost the same value range. In this case either Nutrient Broth (NB) enriched with minerals and inducers or in Luria Bertani (LB) can increase the growth of X.campestris and produced xanthan gum. Other than that from Table 3 it was showed that the dry cell weight and its product meets the average value of xanthan gum industry in general, which contains 10-30 g / L xanthan gum with 1- $10 \mathrm{~g} / \mathrm{L}$ dry cells [6]. It shows that both of $4 \%$ liquid sugar and $2 \%$ maize enriched with mineral can be used to support the growth of X.campestris and also converted into xanthan gum.

Xanthan gum produced from this study yielded varying rendements. The use of $4 \%$ liquid sugar yielded of $34,20 \%-57,88 \%$, while $2 \%$ Maize was $54,93 \%-73,61 \%$. This suggests that most of the $4 \%$ liquid sugar and $2 \%$ maize may be converted to xanthan gum. While based on the dry cell weight, it shows that the small part of both substrates were used to support the growth of X. Campestris [7]. According to Anshor [8], the conversion of glucose substrate to xanthan gum is about $50 \%$. Conversion of glucose into xanthan gum gives a theoretical value of about 70$80 \%$, if fermentation goes well.

Based on its rendement, LBB medium produced a relatively high of $73.61 \%$. From this data it can be mentioned that X.campestris grown in LB medium is better able to convert substrate to its product than grown in NA. The presence of tryptone containing essential amino acids in LB medium will increase the metabolism of $\mathrm{X}$. campestris to produce CGTase enzymes that play a role in the process of starch cyclization and $\alpha-1,4$ glucan to cyclodextrin [5].

The use of NB and LBB produced xanthan gum with viscosity of 28-31 cPs and 15-30 cPs, respectively. Although the viscosity value was still low but these viscosity values indicated that xanthan gum can be used as a thickener in its application in industry [6]. In general, the viscosity value of xanthan gum depends on temperature, biopolymer concentration and $\mathrm{pH}$. In this study the fermentation temperature between 28-300C with a $\mathrm{pH}$ between 6-7. However, in certain conditions, the $\mathrm{pH}$ was often reduced to acidic, this will affect the viscosity of gum xanthan obtained. 
The most common method for gum xanthan refining is the precipitation method using an alcohol solvent. In this research, the purification of the product was tested on three types of solvent ie IPA, acetone and ethanol with the ratio between the products with each solvent 1: 1, 1:2, 1: 3 . From the experimental results it can be shown that the amount of solvent required depends on the nature of the solvent. The best xanthan precipitation was to use 3 and 2 volumes of IPA added with 1 xanthan volume. The addition of salt to a certain concentration will in addition reduce the water affinity of the polymer but there will also be chemical bonds between the cations of the salt and the anions of the xanthan solution, so that the precipitation will increase. According to Ochoa [6], if xanthan is deposited using a combination of salt with IPA then the required amount of IPA will be lower. However, in this study the addition of salt did not provide significant changes to the gum xanthan gain. In the chemical structure of xanthan gum there is a pyruvate and acetal group which is an anionic polysaccharide producer. According to Kennedy and Bradshaw [9], X. campestris can produce xanthan gum with pyruvate and acetal content of $7.1 \%$ and $6.5 \%$ respectively. From the results of this study the acetal and pyruvate content contained in the xanthan amount is still low, so the bond between the cations of the salt and the anions of the xanthan solution is also low. As a result, the addition of salt to the precipitation process does not provide significant changes.

\section{Conclusion}

Based on the FT-IR analysis, showed that the compatibility of functional groups between xanthan gum of the study and commercial gum xanthan, in particular the presence of pyruvate and acetal groups. This suggests that the fermentation of X.campestris using modified Nutrient Broth (NB) and Luria-Bertani Broth (LBB) with 4\% liquid sugar and 2\% maize under certain conditions of process can qualitatively produce xanthan gum.

The use of $4 \%$ liquid sugar yielded of $34.20 \%$ $57.88 \%$, while $2 \%$ maize was $54.93 \%-73.61 \%$. The use of NB and LBB produced xanthan gum with viscosity of 28-31 cPs and 15-30 cPs, respectively. These viscosity values indicated that xanthan gum can be used as a thickener in its application in industry. Precipitation using a combination of salt with IPA did not provide significant changes to the xanthan gum gain. This is due to the low number of bonds between the cations of the salt and the anions of the xanthan solution.

\section{References}

1. M.A. Pulungan,. Kajian Perkembangan Perdagangan Gum Xanthan Sebagai Bahan Pengental Untuk Industri Pangan di Indonesia. Bachelor Thesis of Institut Pertanian Bogor, (1994)
2. A. Palaniraj and V. Jayaraman, J. Food Eng., 106, 1-12 (2011)

3. Djenar N.S and Mulyono E.W.S., Advance Science Letters. 23, 5678-5680 (2017)

4. T. Kometani, Y. Terada, T. Nishimura, H. Takii, S. Okada, J. Biosci. Biotech. Biochem., 58, 1990-94 (1994)

5. D.S. Prastiko, Pengujian Aktivitas Transglikolasi Biakan Xanthomonas campestris Pada Berbagai Sumber Karbohidrat, Bachelor Thesis of Institut Pertanian Bogor, (2011)

6. F. Garcia-Ochoa, VE. Santos, JA. Casas, E. Gómez, Biotechnol Adv., 18, 549-79 (2000)

7. P. Muhiddin $\mathrm{P}$ dan R. Herlina, Bionature, 10 (1): 24-28 (2009)

8. Anshori, Teknologi Fermentasi Industrial, Penerbit Arcan, Bogor (1992)

9. JF. Kennedy JF, IJ. Bradshaw IJ, Prog Ind Microbiol, 19; 319-71 (2004) 